\title{
Karakteristik Fisikokimia dan Uji Aktivitas Antimikroba Bakteriosin Isolat Bakteri Asam Laktat 17B Hasil Isolasi Kolon Sapi Bali
}

\author{
(PHYSICOCHEMICAL CHARACTERISTICS AND ANTIMICROBIAL ACTIVITY TEST OF \\ BACTERIOCINS ORGINATED FROM LACTIC ACID BACTERIA ISOLATES 17B \\ ISOLATED FROM BALI CATTLE COLON)
}

\author{
Nuria Fitrianti Putri ${ }^{1}$, I Wayan Suardana ${ }^{2}$, Iwan Harjono Utama ${ }^{3}$ \\ ${ }^{1}$ Praktisi Dokter Hewan di Kecamatan Denpasar Selatan, Kota Denpasar-Bali, \\ ${ }^{2}$ Laboratorium Kesehatan Masyarakat Veteriner, Fakultas Kedokteran Hewan, Universitas \\ Udayana, Denpasar, Bali. ${ }^{3}$ Laboratorium Biokimia Veteriner, Fakultas Kedokteran Hewan, \\ Universitas Udayana, Denpasar, Bali. \\ *Email: nuria0317@gmail.com
}

\begin{abstract}
ABSTRAK
Bakteri asam laktat (BAL) merupakan suatu mikroorganisme yang bersifat tidak toksik dan mampu menghasilkan senyawa antimikroba, yakni bakteriosin. Penelitian dimulai dari peremajaan isolat 17B dan dilanjutkan dengan produksi dan presipitasi bakteriosin yang dilanjutkan dengan uji sifat kimiawi dan sifat fisik dari bakteriosin. Aktivitas antimikroba bakteriosin isolat 17B dilakukan terhadap bakteri indikator Bacillus cereus FTCC 005. Data hasil penelitian ini disajikan dalam bentuk tabel atau gambar dan analisis secara deskriptif. Hasil penelitian meneguhkan bahwa BAL isolat 17 merupakan bakteri Gram positif dan katalase negatif. Hasil uji sifat kimiawi bakteriosin dari isolat 17B, menunjukkan bahwa bakteriosin yang dihasilkan sebagai senyawa protein yang dibuktikan dengan uji ninhidrin positif, uji Molisch negatif, dan uji lowry positif dengan konsentrasi protein $0,11 \mu \mathrm{g} / \mathrm{ml}$. Hasil karakterisasi sifat fisik dengan menggunakan SDS PAGE menunjukkan bahwa hasil uji negatif. Uji aktivitas antimikroba terhadap bakteriosin menunjukkan efektivitas hambatan sebesar 18,92\%.
\end{abstract}

Kata kunci: bakteri asam laktat; bakteriosin; fisikokimia; kolon; sapi bali

\begin{abstract}
Lactic acid bacteria (LAB) is a microorganism that is not toxic and able to produce antimicrobial compounds, namely bacteriocins. This study aims to determine the physicochemical characterization of bacteriocins origin originated from lactic acid bacteria isolates 17B isolated from colon Bali cattle. The research was started by re-cultivation of isolates $17 \mathrm{~B}$ and continued with production and precipitation of bacteriocins. Further tests were chemical and physical test that, followed by antimicrobial activity test of bacteriocin isolates 17B against Bacillus cereus FTCC 005. Data From this study are presented in tables or figure and analyzed descriptively. Results of study showed that LAB isolates 17B is a Grampositive bacteria and catalase negative. The test also showed the bacteriocins produced isolates 17B as a protein compound indicated by the ninhydrin test positive, Molisch test negative and Lowry test positive with protein concentration was $0,11 \mu \mathrm{g} / \mathrm{ml}$. Physical characterization tested using SDS PAGE showed that the test is negative. Antimicrobial activity test of bacteriocin isolates $17 \mathrm{~B}$ showed that bacteriocin 17B has effectiveness against Bacillus cereus FTCC 005 as 18,92\%.
\end{abstract}

Keywords: Lactic acid bacteria; bacteriocins; physicochemical; colon; bali cattle

\section{PENDAHULUAN}

Bakteri asam laktat (BAL) adalah kelompok bakteri Gram positif, tidak berspora, berbentuk bulat atau batang dan dapat mengubah karbohidrat menjadi asam laktat. BAL mempunyai peranan penting hampir dalam semua fermentasi makanan dan minuman (Korhenen, 2010).

Bakteriosin memiliki $\begin{array}{r}\text { kemampuan } \\ \text { pertumbuhan }\end{array}$
menghambat
mikroorganisme patogen, selain itu
biasanya digunakan sebagai antibiotik
alami dan juga dimanfaatkan sebagai
biopreservasi 4 makanan.
kegunaannya sebagai biopreservasi
makanan, bakteriosin memiliki beberapa
keuntungan, yaitu tidak bersifat toksik dan


mudah mengalami biodegradasi karena bakteriosin ini adalah senyawa protein yang tidak membahayakan mikroflora usus, mudah dicerna oleh enzim-enzim dalam saluran pencernaan, dan aman bagi lingkungan (Suardana, 2007).

Penelitian sebelumnya telah dilaporkan 19 isolat bakteri asal kolon sapi bali. Beberapa isolat telah diteliti positif merupakan bakteri asam laktat (BAL), mampu menghasilkan bakteriosin, dan mempunyai potensi antimikroba terhadap bakteri indikator Staphylococcus aureus yang ditandai dengan adanya daerah hambatan. Pada uji tersebut, dapat disimpulkan bahwa BAL isolat 17B mampu menghambat pertumbuhan bakteri patogen.

Penulisan artikel ini bertujuan untuk mengetahui kemampuan bakteri asam laktat isolat 17B hasil isolasi kolon sapi bali dalam menghasilkan bakteriosin, dan untuk mengetahui karakterisasi fisikokimia bakteriosin asal bakteri asam laktat isolat 17B hasil isolasi kolon sapi bali.

\section{METODE PENELITIAN}

Objek penelitian yang digunakan dalam penelitian ini adalah isolat $17 \mathrm{~B}$ asal $\mathrm{BAL}$ hasil isolasi kolon sapi bali. Prosedur penelitian dimulai dari melakukan sterilisasi alat. Kemudian dilakukan kultivasi BAL isolate 17B dengan melakukan peremajaan (reculture) BAL isolat 17B, pewarnaan Gram, dan uji katalase.

Peremajaan (reculture) isolat dilakukan dengan cara mengambil BAL isolat 17B sebanyak $20 \mu \mathrm{l}$, kemudian dimasukkan ke dalam tabung erlemayer yang berisi $50 \mathrm{ml}$ MRS broth dan diinkubasikan pada suhu $37^{\circ} \mathrm{C}$ selama 24 jam dengan keadaan anaerob. Keberhasilan reculture isolat ditandai dengan adanya kekeruhan pada media MRS broth.

Pewarnaan Gram pada BAL isolat 17B dilakukan dengan mewarnai preparat yang telah difiksasi menggunakan kristal violet $2 \%$, cairan lugol, alkohol aseton, dan srafanin. Uji Katalase dilakukan untuk mengetahui adanya aktivitas enzim katalase. Pada object glass, ditambahkan dua tetes BAL isolat 17B kemudian ditambahkan satu tetes $\mathrm{H}_{2} \mathrm{O}_{2} 10 \%$. Diamati ada tidaknya gelembung oksigen.

Produksi bakteriosin dari BAL isolat 17B dilakukan dengan cara disentrifugasi isolat dengan kecepatan $7.000 \mathrm{rpm}$ selama 10 menit. Supernatan yang diperoleh, kemudian dipresipitasi dengan penambahan ammonium sulfat. Penambahan ammonium sulfat dilakukan secara perlahan-lahan sambil diaduk sampai kejenuhan $70 \%$. Selanjutnya disentrifugasi dengan kecepatan 10.000 rpm selama 10 menit. Kemudian endapan yang didapat ditambahkan dengan larutan $\mathrm{NaCl}$ fisiologis pada perbandingan 1:1 (v/v) (Sudirman et al., 1993).

Uji karakterisasi sifat kimiawi bakteriosin dilakukan dengan uji ninhidrin, uji Molisch, dan uji Lowry. Pada uji ninhidrin, uji ini dilakukan untuk mengetahui dan menentukan adanya asam amino bebas dalam suatu bahan. Hasil uji positif ditandai dengan terbentuknya warna ungu. Uji selanjutnya adalah uji Molisch. Uji Molisch digunakan untuk menentukan adanya karbohidrat dalam suatu bahan. Apabila terbentuk lapisan berwarna ungu berarti uji positif. Uji sifat kimia yang terkhir yaitu uji Lowry. Uji Lowry digunakan untuk menentukan konsentrasi protein dalam suatu sampel dengan mengukur absorpsi dengan menggunakan spektrofotometer. Uji ini menggunakan metode (Lowry et al., 1951).

Setelah dilakukan uji sifat kimia bakteriosin maka dilanjutkan dengan uji karakterisasi sifat fisik bakteriosin dan uji aktivitas antimikroba bakteriosin isolate 17B. Untuk uji sifat fisik bakteriosin dapat dilakukan dengan uji SDS PAGE (Sodium Dodecyl Sulphate Polyacrylamide Gel Electrophoresis) untuk mengetahui bobot molekul bakteriosin.

Uji aktivitas antimikroba dari bakteriosin isolat 17B dilakukan guna mengetahui daya hambat bakteriosin 
terhadap bakteri indikator yang digunakan, yakni Bacillus cereus FTCC 005.

\section{HASIL DAN PEMBAHASAN}

Hasil dari pewarnaan Gram menunjukkan bahwa isolat 17B merupakan bakteri Gram positif, berbentuk basil. Dan pada uji katalase menunjukkan hasil negatif.

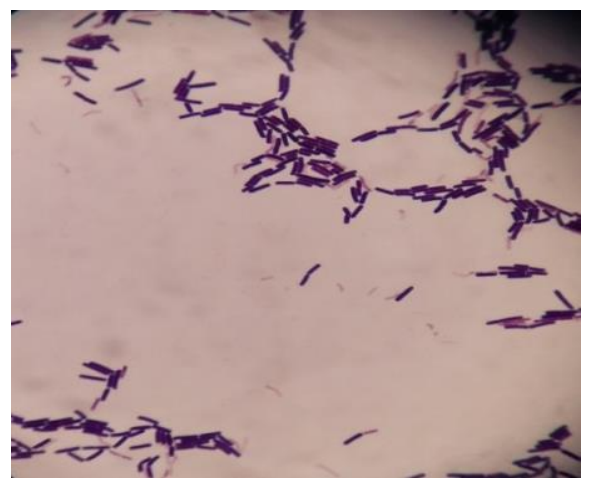

Gambar 1. Hasil uji pewarnaan Gram dibawah mikroskop pembesaran 1000X.

Pada uji karakterisasi kimiawi bakteriosin isolat 17B hasil isolasi kolon sapi bali dilakukan tiga uji yaitu uji ninhidrin, uji molisch, dan uji lowry. Pada uji ninhidrin, bakteriosin isolat 17B memberikan hasil positif.

Pada Gambar 2. Hasil uji ninhidrin terhadap bakteriosin isolat 17B, tanda panah menunjukkan hasil uji A (hasil uji positif) dan B (kontrol negatif).

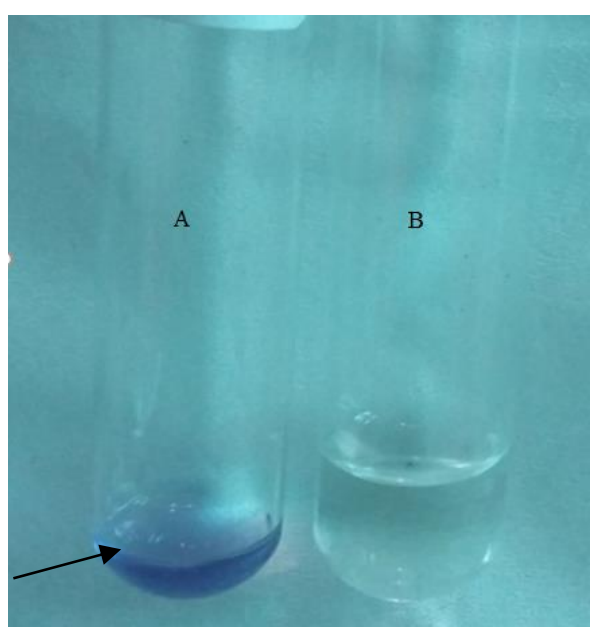

Gambar 2. Hasil uji ninhidrin terhadap bakteriosin isolat 17B.

Pada uji Molisch, larutan bakteriosin menunjukkan hasil yang negatif.

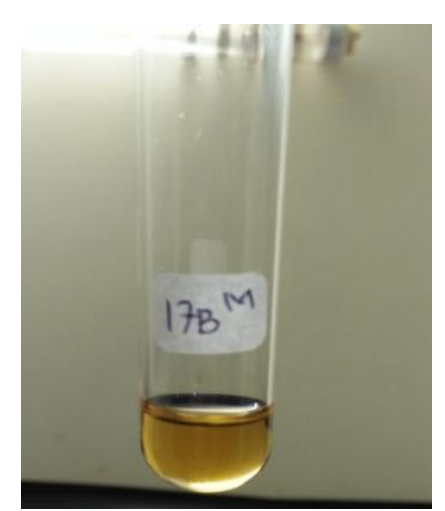

Gambar 3. Hasil uji Molisch terhadap bakteriosin isolat $17 \mathrm{~B}$

Konsentrasi protein dari larutan bakteriosin diuji dengan uji Lowry menggunakan spektrofotometer dengan panjang gelombang $500 \mathrm{~nm}$, Hasil pembacaan nilai OD bakteriosin isolat $17 \mathrm{~B}$ adalah 0.130. Berikut adalah kurva persamaan konsentrasi protein BSA.

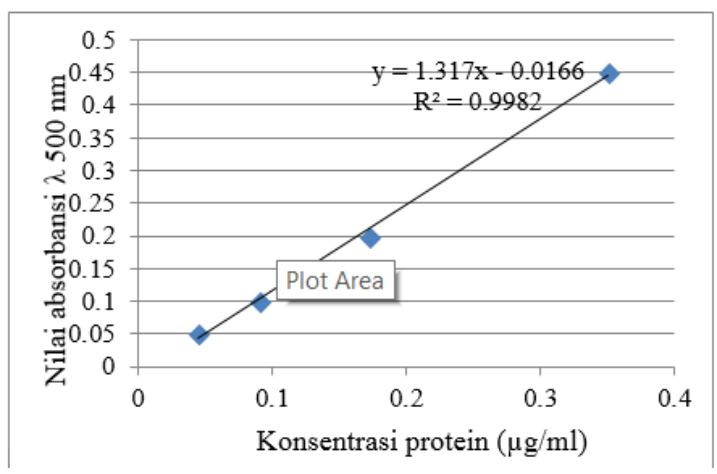

Gambar 4. Kurva persamaan konsentrasi protein BSA

Berdasarkan persamaan di atas, dapat diketahui konsentrasi bakteriosin isolat 17B sebesar $0,11 \mu \mathrm{g} / \mathrm{ml}$. Karakterisasi sifat fisik untuk mengetahui bobot molekul bakteriosin dari isolat 17B hasil isolasi kolon sapi bali diukur dengan menggunakan metode SDS PAGE.

Hasil uji aktivitas antimikroba terhadap bakteriosin menunjukkan bahwa bakteriosin isolat 17B memiliki daya hambat terhadap bakteri indikator Bacillus cereus FTCC 005.

Hasil pewarnaan Gram menunjukkan bahwa BAL isolat 17B merupakan bakteri Gram positif. Dan pada uji katalase, BAL isolat 17B merupakan katalase negatif. Hal ini dikarenakan BAL tidak memproduksi 
enzim katalase sehingga pembentukan gas $\left(\mathrm{O}_{2}\right)$ tidak terjadi.

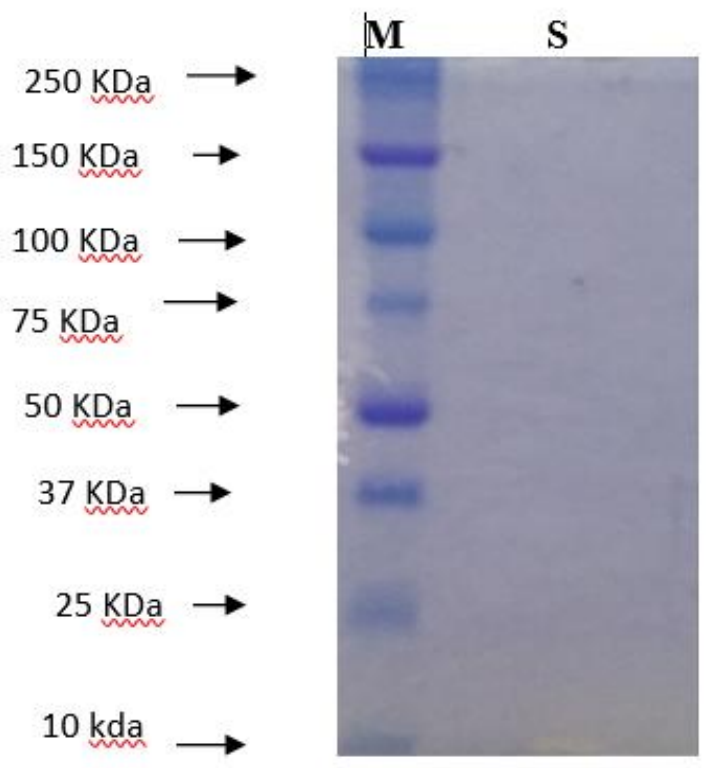

Gambar 5. Hasil uji SDS PAGE bakteriosin dari BAL isolat 17B. Ket: $M=$ Marker protein; $\mathrm{S}=$ Sampel.

Tabel 2. Hasil uji aktivitas antimikroba bakteriosin isolat 17B

\begin{tabular}{lccc}
\hline \multirow{2}{*}{ Bakteriosin } & \multicolumn{3}{c}{$\begin{array}{c}\text { Diameter zona } \\
\text { hambatan }(\mathrm{cm})\end{array}$} \\
\cline { 2 - 4 } & 1 & 2 & 3 \\
\hline 1 & 0.78 & 0.63 & 0.64 \\
2 & 0.61 & 0.63 & 0.75 \\
3 & 0.77 & 0.63 & 0.62 \\
4 & 0.62 & 0.78 & 0.62 \\
5 & 0.62 & 0.79 & 0.61 \\
6 & 0.62 & 0.63 & 0.57 \\
\hline Rataan & 0.67 & 0.68 & 0.63 \\
\hline Konrol positif & 3.9 & 3.42 & 3.2 \\
Kontrol negatif & - & - & - \\
Efektifitas & 17.18 & 19.89 & 19.69 \\
hambatan (\%) & \multicolumn{4}{c}{$18.92 \%$} \\
\hline Rataan
\end{tabular}

Hasil yang diperoleh, bakteriosin isolat 17B pada uji Ninhidrin menunjukkan hasil yang positif ditandai dengan adanya warna ungu pada larutan. Menurut Senese (2010), adanya warna ungu pada larutan disebabkan karena reaksi yang terjadi antara $\alpha$-amino acids dengan ninhidrin.

Selanjutnya pada uji Molisch, bakteriosin isolat 17B menunjukkan hasil uji negatif. Hasil negatif ini menunjukkan bahwa bakteriosin isolat 17B bukan merupakan senyawa karbohidrat. Uji Molisch pada dasarnya menggunakan $\alpha$ napthol yang akan membantu dalam memberikan warna ungu/violet pada suatu senyawa karbohidrat. (Nigam dan Ayyagari, 2007).

Dari hasil uji Lowry, dapat diketahui bahwa konsentrasi bakteriosin isolat 17B adalah sebesar $0,11 \mu \mathrm{g} / \mathrm{ml}$. Yang artinya setiap $1 \mathrm{ml}$ sampel mengandung protein sebesar 0, $11 \mu \mathrm{g} / \mathrm{ml}$. Pada hasil uji menggunakan SDS PAGE, isolat 17B, menunjukkan hasil uji negatif. Hal ini dapat disebabkan karena jumlah konsentrasi sampel yang dimasukkan ke dalam sumuran pada saat uji sedikit, yakni $5 \mu$ l. Janes et al. (1998) dalam penelitiannya, menggunakan sampel sebanyak 10-20 $\mu 1$ untuk satu sumuran. Menurut Rasdiyanah (2014), konsentrasi sampel yang dimasukkan ke dalam sumuran tergantung dari tebal tipisnya pita protein yang diinginkan. Firmansyah (2014) menyatakan bahwa, ukuran molekul protein dan konsentrasi gel juga menentukan laju pergerakan pita protein. Semakin kecil ukuran molekul protein, maka laju pergerakan pita protein akan semakin cepat, sehingga diperlukan konsentrasi gel poliaklilamid yang lebih tinggi agar pergerakan pita protein menjadi lebih lambat.

Hasil uji aktivitas antimikroba terhadap bakteriosin isolat 17B yang merupakan bakteri Gram positif menunjukkan adanya zona hambat pada Bacillus cereus FTCC 005. Bacillus cereus merupakan bakteri Gram positif, berbentuk batang, motil, menghasilkan spora, dan bersifat aerob atau fakultatif anaerob (Bottone, 2010). Menurut Abdelbasset dan Djamila (2008), bakteriosin merupakan peptida antimikroba yang aktif melawan pertumbuhan bakteri dari strain yang berhubungan dekat dengan bakteri penghasilnya. Dilihat dari Tabel 2, bakteriosin isolat 17B memiliki diameter daya hambat yang kecil terhadap Bacillus cereus FTCC 005 dengan efektivitas hambatan sebesar 18,92\%. 


\section{SIMPULAN DAN SARAN}

\section{Simpulan}

Isolat 17B mampu menghasilkan senyawa bakteriosin dengan karakteristik, positif terhadap uji ninhidrin yang menunjukkan bahwa isolat 17B mengandung asam amino, negatif pada uji molisch menunjukkan bahwa isolat 17B ini tidak mengandung senyawa karbohidrat, dan dengan uji lowry diketahui isolat 17B setiap $1 \mathrm{ml}$ memiliki konsentrasi protein sebesar $0.11 \mu \mathrm{g} / \mathrm{ml}$. Bakteriosin yang dihasilkan diketahui membentuk zona hambat terhadap bakteri Bacillus Cereus dengan daya hambat sebesar $18,92 \%$.

\section{Saran}

Hasil uji negatif pada uji SDS-PAGE pada penelitian ini, maka disarankan untuk dilakukan kembali uji SDS-PAGE yang serupa dengan tingkat konsentrasi resolving gel yang lebih besar.

\section{UCAPAN TERIMAKASIH}

Penulis mengucapkan terimakasih kepada Laboratorium Kesehatan Masyarakat Veteriner Fakultas Kedokteran Hewan Udayana dan Balai Besar Veteriner Denpasar, serta kepada semua pihak yang telah mebantu penelitian ini

\section{DAFTAR PUSTAKA}

Bottone EJ. 2010. Bacillus cereus, a Volatile Human Pathogen. Clin. Microbiol. Rev. 23(2): 382-398.

Janes ME, Nannapaneni R, Proctor A, Johnson MG. 1998. Rice Hull Ash and Silicic Acid Adsorbents for Concentration of Bacteriocins. Appl. Environ. Microbiol. 64(11): 44034409.

Korhonen J. 2010. Forestry and Naturals Sciences: Antibiotic Resistance of Lactid acid Bacteria, University of Eastern Finland.

Kusmiati, Malik A. 2002. Aktivitas Bakteriosin Dari Bakteri Leuconostoc Mesenteroides PBacL Pada Berbagai Media. Makara J. 16(1): 1-7.
Lindawati SA, Suardana IW. 2016. Isolasi dan Identifikasi Spesies Bakteri Asam Laktat Penghasil Senyawa Antimikrob Asal Kolon Sapi Bali. J. Vet. 17(4): 576-581.

Nigam A, Ayyagari A. 2007. Lab Manual in Biochemistry, Immunology, and Biotechnology. Tata MCGraw-Hill Publishing Company Limited: New Delhi.

Nuryady MM, Istiqomah $T$, Faizah R, Ufaidillah S, Mahmudi Z, dan Sutoyo. 2013. Isolasi dan Identifikasi Bakteri Asam Laktat Asal Yogurt. UNEJ. 1(5): 1-11.

Rasdiyanah. 2014. Karakteristik Protein dan Komposisi Asam Amino Otot Aktif dan Pasif pada Daging Sapi Bali dan Wagyu. Tesis. Pascasarjana Kedokteran Hewan Universitas Udayana. Bali.

Suardana IW, Suarsana IN, Sujaya IN, Wiryawan KG. 2007. Isolasi dan Identifikasi Bakteri Asam Laktat dari Cairan Rumen Sapi Bali sebagai Kandidat Biopreservatif. J. Vet. 8(4): 155-159.

Suardana IW, Suada IK, Sukada IM dan Suarsana IN. 2009. Isolasi dan Identifikasi Isolat Bakteri Asam Laktat SR9 Asal Cairan Rumen Sapi Bali sebagai Kandidat Unggul Probiotik. Medicina. J. Ilmiah Kedokteran. 40(2): 100-103.

Suardana IW. 2013. Potensi Isolat Lactobacillus brevis 1 Asal Cairan Rumen Sapi Bali sebagai Sumber Senyawa Antimikroba dalam Prosiding Seminar Nasional Sapi Bali "Peran Sapi Bali dalam Mewujudkan Swasembada Daging Nasional yang Berkelanjutan. Bali 24 September 2013. Pp: 87-97.

Suardana IW, Cahyani AP, Pinatih KJP. 2016. Probiotic Potency and Molecular Identification of Lactic Acid Bacteria Isolated from Bali Cattle's Colon, Indonesia. Glo. Adv. J. Med. Med. Sci. 5(5): 143-149. 
Suarsana IN. 2000. Isolasi dan Karakterisasi Substansi Antimikroba yang Dihasilkan oleh Bakteri yang Diisolasi dari Susu Sapi Mastitis. Tesis. Program Pasca Sarjana. IPB, Bogor.

Sudirman IF, Mathiau, Michael M, Lefebvre G. 1993. Detection and Properties of Curvaticin 13, a Bacteriocin Like Substance Produced by Lactobacillus curvatus SB 13. Cur. Microbiol. 27: 35-40.

Widyadnyana DGA, Sukrama IDM, Suardana IW. 2015. Identifikasi Bakteri Asam Laktat Isolat 9A dari Kolon Sapi Bali sebagai Probiotik melalui Analisis Gen 16S rRNA. J. Sain.Vet. 33(2): 228233. 